\title{
Effects of Textile Effluent Fertilization on Germination, Growth and Metabolites of Chilli (Capsicum annum) Cultivars
}

RATAN SINGH

Central University of Gujarat

Dheeraj Rathore ( $\boldsymbol{\sim}$ dheeraj.rathore@cug.ac.in )

Central University of Gujarat https://orcid.org/0000-0002-6608-0926

\section{Research Article}

Keywords: Textile effluent, Capsicum annum, Mineral nutrients, Germination index, Metabolites

Posted Date: February 15th, 2021

DOI: https://doi.org/10.21203/rs.3.rs-226725/v1

License: (c) (1) This work is licensed under a Creative Commons Attribution 4.0 International License.

Read Full License 
1 Title: Effects of Textile Effluent Fertilization on Germination, Growth

2 and Metabolites of Chilli (Capsicum annum) Cultivars

3 Running Title: Effects of Textile Effluent on Chilli

5 Authors

6 RATAN SINGH AND DHEERAJ RATHORE*

$7 \quad$ Affiliation

8 School of Environment and Sustainable Development, Central University of Gujarat,

9 Gandhinagar (India).

10

11 *Corresponding author: School of Environment and Sustainable Development, Central

12 University of Gujarat, Sector-30, Gandhinagar-382030, Gujarat, India.

13 E-mail: dheeraj.rathore@cug.ac.in

14 ORCID: 0000-0002-6608-0926 (Dheeraj Rathore)

15

16 


\section{Abstract}

Nutrients deficiency in soil suppresses crop growth, yield and nutritional value of the products. Textile effluent, a rich source of several essential minerals $(\mathrm{Ca}, \mathrm{Mg}, \mathrm{Cu}, \mathrm{Fe}, \mathrm{Zn}$, $\mathrm{Mn}$, etc.) required for the plant growth, could be a vital option to supplement minerals to accomplish the nutrient availability of soil. Although presence of some toxic metals and organic compound restrict its use as irrigation water, its controlled use as fertilizer was not studied so far. This study was undertaken to assess the eco-friendly utilization method of textile industry effluent by applying the same into chilli (Capsicum annum L.) cropping system for its suitability and potentiality as macro and micronutrient supplement. Result of the experiment showed no inhibitory effect of textile effluent on seed germination, while its fertilization as soil drench worked as nutrient supplement for growth in chilli cultivars. Textile effluent fertilization enhances plant biomass up to $32124.47 \%$ and $110.85 \%$ in chilli cultivar GVC-101 and GVC-121, respectively. Total carbohydrate and foliar protein was also favoured by effluent fertilization. Lower RSR and least proline accumulation suggested reduced stress due to textile effluent fertilization. Study concluded that the lower dose of textile effluent fertilization can

36 function as nutrient supplement with chilli cultivars and $20 \%(\mathrm{v} / \mathrm{v})$ dilution provide most

37 favourable results.

38 Keywords Textile effluent; Capsicum annum; Mineral nutrients; Germination index;

39 Metabolites 


\section{Article Highlight:}

1. Management of hazardous textile effluent is a global issue. Application of textile effluent to agricultural field could be a viable option.

2. Application of textile effluent enhances germination of chilli cultivars.

3. Lower dose of textile effluent fertilization provided nutrients to the chilli plants and increases growth.

\section{Introduction}

Textile industry is one of known water intensive industries, consuming large quantity of water for various processes and discharge equally large volumes of waste water containing a variety of pollutants. Unimpeded disposal of textile effluent not only poses risks to human, animal and plant health but also possess serious threats to soil and water body and disrupt ecology of affected areas. Textile effluent can induce mutations, causes genotoxicity and oxidative damage, root growth retardation, mito-depression, and induction of chromosomal abnormalities in root meristematic cells (Hemachandra and Pathiratne 2016; Akhtar et al. 2016).

On the other hand, micronutrients deficiency in soil and plants is a global nutritional problem and is prevalent in many countries with different magnitude of severity. Micronutrient deficiencies in soil have been identified as one of the main factors affecting crop yield and food quality, which resulted in reduced nutrient in diet (Cakmak 2002). The industrial effluent contains several macro and micronutrients in the form, which plants can take for their growth. Application of such effluent in agricultural fields may be a viable option to dispose industrial effluent, and would sustain agriculture in non-irrigated areas where the availability of fresh water is scarce (Kumar and Chopra 2013). Moreover, waste water can provide important nutrients, especially nitrogen and 
66 phosphorus and some micro-nutrients, which can increase soil fertility and enhance plant

67 growth, crop production and quality of produce. It also reduces the requirements for commercial chemical fertilizers and thus increases farmer's economic benefits

69 (Papadopoulos and Savvides 2003). Fertilization by effluent provided dual benefit to the 70 environment as it reduces the requirement of chemical fertilizer besides resolving the problem of effluent disposal.

Composite effluent from textile industries consist high concentration of heavy metals and organic compounds. Some metals, necessary for plant metabolism as enzyme activators or regulators e.g. $\mathrm{Fe}, \mathrm{Cu}, \mathrm{Mn}, \mathrm{Mo}$, are present in textile effluent, but may cause toxicity if supplied in excess (Kaushik et al. 2005). Use of wastewater reduces fertilizer and irrigation cost as it is available without paying any cost (Papadopoulos and Savvides 2003). Earlier researches with lower dose of distillery effluent as irrigation provided positive results on seed germination, total sugars, starch, reducing sugars, and chlorophyll (Ramana et al. 2002).

The studies conducted so far on the utilization of textile effluent in agriculture were focused on nutrient utilization during irrigation. However, presence of high salinity and significant amount of trace metal can harm the crop and soil by its continuous application as irrigation. So far, no study was seen for application of limited amount of textile effluent as fertilizer dose to harvest the nutrient potential of the textile effluent. The present study aimed eco-friendly disposal of textile industry effluent and supplement the micronutrient during cultivation of chilli (Capsicum annum L. cv.GVC-101 and GVC121) by fertilization with different concentration of effluent and assess the agropotentiality and suitability of the optimum effluent concentration. 


\section{Effluent collection and characterization}

92

93

94

95

96

97

98

99

100

101

102

103

104

105

106

107

108

109

110

111

Textile effluent originating from the Mangalam textile industry was collected from a Green Environment CETP located in Vatwa (Singh and Rathore 2020) before treatment process. Collected effluents were stored in refrigerator $\left(4{ }^{\circ} \mathrm{C}\right)$ to avoid changes in its characteristics during storage. As the textile effluent used is the present study was same of our previous studies (Singh and Rathore 2018, 2020), physico-chemical characterisation, analysed using standard methods described in APHA (2012), was also similar (Table S1) and reported before in Singh and Rathore $(2018,2020)$.

\section{Germination experiment}

Wet cotton method was applied for germination experiment. Cotton was moistened with $10 \mathrm{ml}$ water for control and with the same quantity of different concentrations of textile effluent dilution $(10 \%, 20 \%, 40 \%$ and $60 \% \mathrm{v} / \mathrm{v})$ in water and kept in a petri dish. 8 seeds of both cultivars were placed in these petri dish. Petri dishes were incubated at 30 $\pm 1^{\circ} \mathrm{C}$ temperature. Germination was recorded every 5 days from the date of sowing for 15 days at 11 am, and the emergence of the radicle was taken as a criterion of germination. All the experiments were carried out in three replication (3 petri dishes for each treatment) and the result was averaged.

Seed germination under different effluent concentration was recorded and computed for germination percent. Speed of germination was analysed using the following formulae-

Speed of germination $=\frac{\text { No.of seeds germinated }}{\text { days of the first count }}+\cdots+\cdots+\frac{\text { No.of seeds germinated }}{\text { days of the final count }}$.

Peak value and germination value was calculated using formulae explained by Kaushik et al. (2005). 
Vigor index $=$ Germination percent $\times$ mean of seedling length (root + shoot $)$ at the

\section{Pot experiment material and design}

Two cultivars of chilli (Capsicum annum) i.e. GVC-101 and GVC-121 obtained from Anand Agricultural University, Anand, Gujarat. Both cultivars are Kharif-Rabi season variety, but different in their morphology, biochemical characteristics, nutritional composition and yield potential (http://www.aau.in; Litoriya et al., 2014). Genetically uniformed seeds of chilli were sown in pots of $19 \mathrm{~cm}$ (diameter) $\times 18 \mathrm{~cm}$ (height) size. Pots were filled with equal amounts of slightly alkaline ( $\mathrm{pH} 7.8$ and EC $\left.0.53 \mu \mathrm{Scm}^{-1}\right)$ sandy loam soil of medium fertility (NPK value of used soil is $236.31,78.63,118.54 \mathrm{~kg} \mathrm{ha}^{-1}$, respectively). Twelve seeds of chilli cultivars were sown in each pot. Four dilution of textile effluent $(10 \%, 20 \%, 40 \%$ and $60 \%$ v/v i.e. T1, T2 T3 and T4 respectively) was applied in soil as the basal fertilizer dose for micronutrient supplementation (Table S2). Fertilization with textile effluent have applied only once during the whole experiment. A control set (without textile effluent fertilization), were also maintained for comparison. Ground water was applied for irrigation purpose in all treatments. After germination seeds were thinned to six seedlings per pot in all the pots, which were further thinned at 
each sampling period. Experiment was conducted under completely randomized designed and replicated by three times.

\section{Plant growth analysis}

Plants were randomly sampled in triplicate from all treatment at 30, 60, 90 and 120 days after sowing (DAS). After carefully washing with distilled water, plants were separated into roots, stem and leaves. Plant height (roots and shoot length) was measured by meter scale and leaf area was measured by graphical method and presented as $\mathrm{cm}^{2}$ plant $^{-1}$. To determine biomass, plant parts were oven-dried at $80^{\circ} \mathrm{C}$ till a constant weight was achieved. After drying, the plant parts were weighed by weighing balance. Root to shoot ratio (RSR) was calculated according to Hunt and Burnett (1973).

\section{Photosynthetic pigments}

For chlorophyll and carotenoid determinations, $0.1 \mathrm{~g}$ leaf sample was placed in $10 \mathrm{ml}$ of $80 \%$ acetone in a test tube and kept it overnight in a refrigerator at $4^{\circ} \mathrm{C}$. It was then homogenized and centrifuged at $6000 \times \mathrm{g}$ for 15 minutes. The optical densities of the supernatant were measured at 480, 510, 645 and $663 \mathrm{~nm}$. The contents of chlorophyll $a, b$ and carotenoid were calculated by using the formulae described by Machlachlan and Zalik (1963) and Duxbury and Yentsh (1956), respectively. Total chlorophyll was obtained by adding the value of chlorophyll $a$ and chlorophyll $b$.

\section{Metabolites and proline content}

For carbohydrate, $1 \mathrm{gm}$ of fresh leaf sample was crushed with chilled $70 \%$ ethanol and centrifuge at $4000 \mathrm{rpm}$ for $10 \mathrm{~min}$. After centrifugation, $1 \mathrm{ml}$ of obtained supernatant was added with freshly prepared $4 \mathrm{ml}$ of Anthrone reagent and mixture was allowed to 
stand in warm water for 8-10 min than cooled rapidly and absorbance was read to estimate total carbohydrate content as described by Yemm and Willis (1954).

Protein was estimated by leaf extraction in $0.2 \mathrm{M}$ phosphate buffer of $\mathrm{pH} 7$ following the method of Lowry et al. (1951). Amount of protein present in the samples was expressed with the bovine serum albumin (BSA) as standard in $\mu \mathrm{g} / \mathrm{ml}$.

Proline content was estimated by extracting the leaf sample in $10 \mathrm{ml}$ sulfosalicylic acids and supernatant was used for acid-ninhydrin test (Bates et al. 1973) and expressed as $\mu \mathrm{mol}$ proline $\mathrm{g}^{-1} \mathrm{FW}$.

\section{Statistical analysis}

The data for different treatment were presented as mean value of three replicate. Average of three replications and their standard errors were calculated. The significance of the data was analysed using two ways ANOVA, growth stage and treatments were considered as two factors. Statistical analyses were performed using the SPSS program (version 17.0) to compare the effect of textile effluent fertilization and plant age. Plant photosynthetic pigment content, biochemical characterisation, and biomass assay were compared by analysis of variance and multiple comparison tests. In case of significant changes, heterogeneous groups were distinguished on the basis of Duncan test multiple range test at $\mathrm{p}<0.05$.

\section{Results}

\section{Effluent characteristics}

Used textile effluent is brownish in colour, deficit in dissolved oxygen, rich in total solids, total alkalinity, high biological oxygen demand (BOD) and chemical oxygen demand (COD) with considerable amounts of total nitrogen, phosphate, chlorides, 
sulphate, sodium, calcium, zinc, manganese, copper, nickel, ferrous, lead and cadmium (Singh and Rathore 2018). Concentration of total suspended solid (TSS), BOD, COD, and Total dissolved solid (TDS) content of studied effluent exceeded the prescribed limit of Indian irrigation standard (BIS 1991).

\section{Germination experiment}

Textile effluent dilution favoured well for both chilli cultivars in germination experiment. Both the cultivars showed increase in percentage germination by all the dilution of textile effluent except a slight decrease at T4 dilution in GVC-101. Germination percent was also higher than control in both the cultivars after dilution of textile effluent (Table 1).

Peak value (PV), germination value $(\mathrm{GV})$ and seed vigor index (SVI) was also increased by addition of textile effluent in both the cultivars with highest increase at $\mathrm{T} 1$ treatment except SVI of GVC-121 which was found highest at T2 treatment. Delay index was nil at T1 and T2 treatment for GVC-101 and at T1 treatment for GVC 121.

\section{Plant growth}

Application of textile effluent showed positive response for shoot height and root length in both the chilli cultivars (Fig. 1a) at all the ages. For shoot height, most suited fertilization dose of textile effluent was T2 at all the ages except 30 DAS in GVC-101. Highest shoot length of cultivars GVC-101 and GVC-121, were $31.17 \%$ and $39.25 \%$, respectively at 120 DAS in T2 treatment while, root length was highest in T3 treatment at 120 DAS (31.56\% and $18.91 \%$ for GVC-101 and GVC-121, respectively).

Two factor analyses showed significant variation for all the factors in both cultivars except interaction of age $\times$ treatment for GVC-101 of root length (Table S3). 
Similar to plant height, leaf area was also increased by textile effluent fertilization in

205

206

207

208

209

210

211

212

213

214

215

both the studied cultivars and best result was seen with T2 treatment (Fig. 1b). Increase in leaf area was significant by both the factors i.e. plant age and fertilization dose and its interaction for both experimental cultivars (Table S3). Highest leaf area was found at 60 DAS with T2 treatment i.e. 26.59 and $21.46 \mathrm{~cm}^{2}$ plant ${ }^{-1}$ for cv. GVC-101 and GVC-121, respectively.

Plant biomass was significantly increased at successive growth stages in all the textile effluent fertilization regimes except at $30 \mathrm{DAS}$ in $\mathrm{T} 1$ and $\mathrm{T} 3$ treatment for GVC121 (Fig. 1c). Increase was highest at 120 DAS. Application of textile effluent fertilization with $20 \%$ (T2) dilution was found most suited for total biomass accumulation in both the cultivars. Highest increase of total dry biomass was recorded with T2 treatment at 120 DAS for both the chilli cultivars i.e. $43.78 \%$ and $42.19 \%$ for GVC-101 and GVC-121, respectively against their respective controls. .

\section{Photosynthetic pigments and plant metabolites}

Chlorophyll ' $a$ ' accelerated significantly from 30 to 120 days in both the cultivars at all the textile effluent fertilization regime except at 120 DAS for GVC-121 (Fig. 2a). Increase in chlorophyll ' $a$ ' was found maximum at 120 DAS $(45.25 \%$ and $32.66 \%$ for GVC101 and GVC-121 respectively) with T2 treatment than their respective controls. Similar to $\mathrm{Chl}$ ' $a$ ', Chl ' $b$ ' was also increased in the similar trend (Fig. 2b). Plant fertilized by $40 \%$ (T3 treatment) textile effluent exhibited maximum content of total chlorophyll (46.32 and 35.07\% respectively for cultivar GVC-101 and GVC-121)) than control at 120 DAS (Fig. 2c).

Carotenoids content recorded an increase with successive plant age (Fig. 2d). Textile effluent fertilization further enhances carotenoids synthesis in both experimental plant 
cultivars. Enhancement was higher with higher dose of textile effluent fertilization. Highest carotenoid in both the cultivars was present at 90 DAS with T3 treatment. Statistically, effect of age, treatment and its interaction was highly significant with both the cultivars (Table S3).

Total carbohydrate content was affected positively by textile effluent fertilization in both chilli cultivars (Fig. 3a). Increase in carbohydrate was higher for T1 and T2 treatments. Highest increase in total carbohydrate content was seen in T2 treatment at 90 DAS for GVC-101 (78\%) and in T2 treatment at 120 DAS for GVC-121 (83\%). Similar to total carbohydrate, protein content was also increased significantly under textile effluent application at all ages with all the treatments in both the tested cultivars (Fig. 3b). Protein content observed maximum in GVC-101 (72.92\%) at T2 after 120 DAS. Order of the increase was $\mathrm{T} 2>\mathrm{T} 1>\mathrm{T} 3>\mathrm{T} 4$ in both cultivars compare to their respective control. Variation in total carbohydrate and total protein was highly significant by both the factors viz. age and textile effluent fertilization and their interactions (Table S3).

Contrary to carbohydrate and protein, proline accumulation was reduced at successive ages by textile effluent fertilization in respect to their control except at 30 DAS, where it was found higher in control (Fig. 3c). Proline accumulation was least with $\mathrm{T} 2$ fertilization in both cultivars. Analysis of variance showed highly significant effect of factor age and fertilization, although factor interaction was non-significant (Table S3).

\section{Discussion}

Textile effluent plays a major role in producing large amounts of water pollution by characteristic toxicity of its effluent i.e. higher total hardness, TDS, BOD, COD, $\mathrm{SO}_{4}, \mathrm{Ca}$ $\mathrm{Mg}, \mathrm{Pb}, \mathrm{Cd}$ etc. However, appreciable amount of mineral nutrients such as $\mathrm{Ca}, \mathrm{Fe}, \mathrm{Mg}$, $\mathrm{Zn}, \mathrm{Cu}$, and $\mathrm{Mn}$ are also present in the textile effluent (Kaushik et al. 2005; Singh et al. 
252 2015) making its a possible source of fertilizer. The fertilization property of textile

253 effluent is well discussed in our earlier published report (Singh and Rathore 2018).

254 Panda et al. (2016) in his experiment with Oryza sativa demonstrated that the lower

255 concentrations of industrial effluents promote seed germination, seedling growth and dry

256 matter accumulation. Textile effluent used for present study was having appreciable

257 amount of plant mineral nutrient which increases the possibility of using this waste as a

258 source of plant nutrient in agricultural soil. Although, high COD, total solid, total

259 dissolve solid, soaring alkalinity with higher value of chloride and sulphate can make soil

260 alkaline and reduce availability of micronutrients. Results of the present study indicate

261 the fertilization of textile effluent in lower dilution increasing the germination property,

262 growth and metabolites of chilli cultivars.

263 The present experiment showed positive response of textile effluent on germination.

264 Earlier researchers (Kaushik et al. 2005; Khan et al. 2011) observed increase in

265 germination of wheat, pea, lentil and gram with low dilution of textile effluent while a

266 decrease in seed germination with increase in the concentration of the effluent. Result

267 showed higher seed germination as compare to control in all the used dilution of textile

268 effluent (up to $60 \%$ dilution) in cultivar GVC-101 however, germination of cultivar

269 GVC-121 was increased up to $40 \%$ dilution and reduced with $60 \%$ dilution as compare to

270 control. Industrial effluent with high osmotic pressure can cause reduction in germination

271 (Kaushik et al. 2005; Khan et al. 2011). However, germination percent was varies with

272 the cultivars of same species as seen in this experiment. The maximum promoting effect

273 on germination percent was observed with $10 \%$ dilution of textile effluent in both the

274 cultivar.

275 In the present study, germination speed, peak value and germination value also

276 followed the same trend as seed germination. Speed of germination is maximum in $10 \%$ 
dilution and reduced with increase in textile effluent concentration. Ajouri et al. (2004) suggested that the minimum speed of germination is in control (without treatment) may be due to nutrient unavailability as well as nutrient deficiency in soil. The reason for the germination inhibition in the higher concentration of textile effluent can be explained as the toxic effect of heavy metals and persistent organic compound present in the composite textile effluent (Singh and Rathore, 2019). Delay index calculated in present experiment also showed delayed germination due to higher dose of textile effluent while vigor index showed vigorous characteristic of used seed with moderate dose of textile effluent. This result is consistent with Ramana et al. (2002) in some vegetable crops effluent fertilization were also increased over control plants. However, fertilization of lower dose textile effluent provided more persistent results as compare to high dose. Deficiency of nutrient in the soil suppress the growth of plant while accumulation of salts such as $\mathrm{Cd}$ that could interfere with the uptake of various nutrient elements, decrease root respiration and inhibit root production (Bhuiyan et al. 2016). Contrary to the results obtained in the present study, Marwari and Khan (2012) reported reduction in root and shoot length by textile effluent. reduction of crop growth. Increase in leaf area can be correlated with increase in photosynthetic activity and higher production. Faster development of leaf size and increase in total photosynthetic rate could lead to a general increase of carbon assimilation as evident in the present experiment by increased plant biomass. Similar result also obtained by Kaushik et al. (2005) on growth and biomass of wheat cultivars 
and cowpea with textile sludge. However, increase in root:shoot ratio (RSR) during fertilization with higher concentration of textile effluent suggested increased stress due to higher salinity or by trace elements present in the effluent.

Chlorophyll estimation is one of the important plant parameters which are used as an index of production capacity of the plant and carotenoids act as an accessory pigment in photosynthesis. Increase in chlorophyll could be due to addition of nutrient by textile effluent fertilization while high concentration of micronutrient showed synergistic effect on either chlorophyll synthesis pathways or on enzymes used for synthesis. Srivastava and Sahai (1988) supported the view that the increase in carotenoid content at low concentrations of the effluent treatment may be due to the beneficial effect of nitrogen and other inorganic elements present in the textile effluent.

Total carbohydrate and protein content showed similar trend as chlorophyll and increased with age and textile effluent fertilization. Increase in carbohydrate with age may be expected, as starch is converted to carbohydrate as the plants mature (Badoni et al. 2016). Although, suppression of carbohydrate content by high concentration of composite textile effluent can be explained as by presence of high amount of metals ( $\mathrm{Zn}$, $\mathrm{Mn}, \mathrm{Cu}$ etc.) and role of carbohydrate in the enzymatic reactions related to the cycles of carbohydrate catabolism during reactive oxygen species (ROS) generation. Similar to our result, Badoni et al. (2016) also reported an increased accumulation of carbohydrate with increasing concentration of $\mathrm{Zn}$ as compared to the control in Jatropha curcas. Amino acid is the basic precursors for the protein that take part in photosynthesis and photosynthetic pigments and leaf protein content may positively correlated with biomass and total chlorophyll content of plant (Ayyasamy et al. 2008).

Increase in protein under textile effluent fertilization was corresponding to carbohydrate. However, gradual decrease of protein content at higher concentration 
(above $20 \%$ to $60 \%$ ) suggested the breakdown of protein in amino acid due to stress

328

329 generated in the presence of the toxic concentration of heavy metals in the textile effluent. However, as explained by Rehman and Bhatti (2009) the enhancement in leaf protein exposed to the lower concentration of textile effluent by synthesis of stress protein gradually from 30 DAS up to 120 DAS.

Proline is a stress amino acid synthesized according to the defensive capability of plants. The accumulation of proline in plant tissue increase due to stress generated during the growth phase (age of the plant) or in different environmental conditions i.e. heavy metals, UV light, drought, air pollution etc (Agrawal et al., 2004; Rathore and Chaudhary, 2019, Singh and Rathore, 2019). In presented study, proline accumulation increased in T4 due to the heavy metals and salt stress. Stress generated from nutrient deficiency in soil can also cause proline accumulation in plant (Arias-Baldrich et al. 2015) which can be seen in high concentration of proline in control plants (without textile effluent fertilization).

\section{Conclusion}

Textile effluent is rich in nutrients for plants all together unwanted and surplus trace elements and high salt content. Positive response of lower dose (with 20\% dilution) of textile effluent fertilization on germination, growth and metabolites of chilli cultivars represented mineral utilization from the effluent. Mineral deficiency or excess mineral developed stress symptoms in plants which can be evident by higher proline accumulation or high RSR as seen in present study with no fertilization or higher textile effluent fertilization. Lower dose of textile effluent fertilization accumulated least proline proved a most suited condition for chilli growth. Intra-specific variation among the chilli cultivars GVC-101 and GVC-121 to textile effluent was not much evident. Although, slightly higher efficiency was seen in cultivar GVC-101 as compare to cultivar GVC-121 
352 for nutrient utilization from textile effluent. Study concluded that the lower dose of

353 textile effluent can be applied as mineral nutrition supplement for plant growth.

354 However, at this point variable nutrient use efficiency among the cultivars from textile

355 effluent cannot be concluded.

\section{Declaration:}

357 Funding: Not applicable

358 Competing interests: Authors declare no competing interest

359 Ethics approval and consent to participate: Not applicable

360 Consent for publication: Not applicable

361 Availability of data and materials: Not applicable

362 Authors' contributions:

363 RS carried out the experiment, recorded the data, interpreted the result, and wrote the

364 final manuscript. DR designed and supervised the experiment, made suitable changes in

365 the manuscript. Both author's read and approved the final manuscript.

366 Acknowledgments Authors would like to thanks to GFRF (Gujarat Forest Research 367 Foundation) Gandhinagar, Gujarat and School of Environment and Sustainable 368 development, Central university of Gujarat to make available the space and required 369 experimental facility, respectively for the present research work. Authors are also 370 thankful to Dr R.R. Acharya, Anand agricultural university, Anand (Gujarat, India) for 371 providing seeds. One of the authors (Miss Ratan Singh) is highly thankful to Ministry of 372 Social Justice and Empowerment for RGNFD fellowship (RGNF-2012-13DGEN-UTT373 56466).

\section{Reference.}


Abdul-Baki AA, Anderson JD (1973) Vigor determination in soybean seed by multiple criteria 1. Crop Sci 13: 630-633.

Agrawal SB, Rathore D, Singh A (2004) Combined effects of Enhanced UV-B radiation and Additional Nutrients on two Cultivars of Wheat (Triticum aestivum L). Physiol Mol Biol Plants 10(1): 99-108.

Ajouri A, Asgedom H, Becker M (2004) Seed priming enhances germination and seedling growth of barley under conditions of $\mathrm{P}$ and $\mathrm{Zn}$ deficiency. J Plant Nutr Soil Sci 167: 630-636.

Akhtar MF, Ashraf M, Anjum AA, Javeed A, Sharif A, Saleem A, Akhtar B (2016) Textile industrial effluent induces mutagenicity and oxidative DNA damage and exploits oxidative stress biomarkers in rats. Environ Toxicol Pharmacol 41: 180186.

American Public Health Association (APHA) (2012) Standard Methods for Examination of Water and Wastewater (22nd ed.). 2012. Washington, DC, US.

Araújo ASF, Monteiro RTR, Carvalho EMS (2007) Effect of composted textile sludge on growth, nodulation and nitrogen fixation of soybean and cowpea. Biores Technol 98: 1028-1032.

Arias-Baldrich C, Bosch N, Begines D, Feria AB, Monreal JA, García-Mauriño S (2015) Proline synthesis in barley under iron deficiency and salinity. J Plant Physiol 183: 121-129.

Ayyasamy PM, Yasodha R, Rajakumar S, Lakshmanaperumalsamy P, Rahman PKSM, Lee S (2008) Impact of sugar factory effluent on the growth and biochemical characteristics of terrestrial and aquatic plants. Bullet Environ Contam Toxicol 81: 449-454. 
Badoni P, Kumari M, Patade VY, Grover A, Nasim M (2016) Biochemical and Physiological analysis of Zinc Tolerance in Jatropha curcas. J Exp Biol 4: 1.

401

Bates LS, Waldren RP, Teare ID (1973) Rapid determination of free proline for waterstress studies. Plant Soil 39: 205-207.

403

404

405

406

407

408

409

410

411

412

Bhuiyan MR, Rahman MM, Shaid A, Bashar MM, Khan MA (2016) Scope of reusing and recycling the textile wastewater after treatment with gamma radiation. $\mathbf{J}$ Clean Prod 112: 3063-3071.

BIS (1991) Specifications for Drinking Water, IS:10500: 1991, Bureau of Indian Standards, New Delhi, India.

Cakmak I (2002) Plant nutrition research: Priorities to meet human needs for food in sustainable ways. Plant Soil 247: 3-24.

Duxbury AC, Yentsch CS (1956) Plankton pigment nomographs. J Marine Res 16: 92101.

Hemachandra CK, Pathiratne A (2016) Combination of physico-chemical analysis, Allium cepa test system and Oreochromis niloticus erythrocyte based comet assay/nuclear abnormalities tests for cyto-genotoxicity assessments of treated effluents discharged from textile industries. Ecotoxicol Environ Saf 131: 54-64.

Hunt R, Burnett JA (1973) The effects of light intensity and external potassium level on root/shoot ratio and rates of potassium uptake in perennial ryegrass (Lolium perenne L.). Ann Bot 37: 519-537.

Kaushik P, Garg VK, Singh B (2005) Effect of textile effluents on growth performance of wheat cultivars. Biores Technol 96: 1189-1193.

Khan MG, Daniel G, Konjit M, Thomas A, Eyasu SS, Awoke G (2011) Impact of textile waste water on seed germination and some physiological parameters in pea 

L.). Asian J Plant Sci 10: 269-273.

425

Kumar V, Chopra AK (2013) Response of sweet sorghum after fertigation with sugar mill effluent in two seasons. Sugar Tech 15: 285-299.

Litoriya NS, Gandhi K, Talati JG (2014) Nutritional composition of different chilli (Capsicum annuum L.) varieties. Ind J Agr Biochem 27(1): 91-92.

Lowry OH, Rosebrough NJ, Farr AL, Randall RJ (1951) Protein measurement with the Folin phenol reagent. J Biol Chem 193: 265-275.

Maclachlan S, Zalik S (1963) Plastid structure, chlorophyll concentration, and free amino acid composition of a chlorophyll mutant of barley. Can J Botany 41: 1053-1062.

Marwari R, Khan TI (2012) Effect of textile waste water on tomato plant, Lycopersicon esculentum. J Environ Biol 33: 849-854.

Panda D, Bagh S, Palita SK (2016) Impact of Industrial Effluents on Seed Germination, early Seedling Vigor of Rice (Oryza sativa L.) its Sustainable Use in Agriculture. Environ Ecology 34: 155-159.

Papadopoulos I, Savvides S (2003) Optimisation of the use of nitrogen in the treated wastewater reused for irrigation. Water Sci Technol: Water Sup 3: 217-221.

Ramana S, Biswas AK, Kundu S, Saha JK, Yadava RBR (2002) Effect of distillery effluent on seed germination in some vegetable crops. Biores Technol 82: 273275.

Rathore D, Chaudhary IJ (2019) Ozone risk assessment of castor (Ricinus communis L) cultivars using open top chamber and ethylenediurea (EDU). Environ Pol 244: $257-269$. 
446 Rehman A, Bhatti HN (2009) Textile effluents affected seed germination and early growth of some winter vegetable crops: a case study. Water Air Soil Pol 198(14): $155-163$.

Singh L, Sharma P, Pavankumar AR (2015) Chemical oxygen demand elimination and decolorization of textile industrial effluent by an indigenous fungal species Aspergillus foetidus. CLEAN-Soil Air Water 43: 456-461.

452 Singh R, Glick BR, Rathore D (2020) Role of textile effluent fertilization with

Srivastava N, Sahai R (1988) Ecophysiological response of certain crop plants of eastern

467 Yemm EW, Willis AJ (1954) The estimation of carbohydrates in plant extracts by 
472 Table 1. Effects of textile effluent on Germination percent (GP), Speed of germination (SOG), peak value (PV), germination value (GV), seed

473 vigor index (SVI) and delay index (DI) of chilli (Capsicum annum) cultivars GVC-101 and GVC-121*.

\begin{tabular}{|c|c|c|c|c|c|c|c|c|c|c|}
\hline \multirow[t]{2}{*}{ Parameters } & \multicolumn{5}{|l|}{ GVC-101 } & \multicolumn{5}{|l|}{ GVC-121 } \\
\hline & $\mathbf{C}$ & T1 & $\mathbf{T 2}$ & T3 & T4 & $\mathbf{C}$ & T1 & $\mathbf{T 2}$ & T3 & T4 \\
\hline GP & $56.67 \pm 0.04^{\mathrm{a}}$ & $85.78 \pm 1.03^{b}$ & $77.89 \pm 0.11^{\mathrm{ab}}$ & $74.11 \pm 0.05^{\mathrm{ab}}$ & $62.00 \pm 0.04^{\mathrm{ab}}$ & $68.33 \pm 1.33^{\mathrm{a}}$ & $88.00 \pm 0.01^{\mathrm{a}}$ & $82.22 \pm 0.15^{\mathrm{a}}$ & $69.00 \pm 0.02^{\mathrm{a}}$ & $65.11 \pm 0.17^{\mathrm{a}}$ \\
\hline SOG & $21.81 \pm 1.42^{b}$ & $30.35 \pm 1.09^{\mathrm{e}}$ & $26.73 \pm 0.01^{\mathrm{d}}$ & $25.27 \pm 0.08^{c}$ & $21.17 \pm 0.03^{\mathrm{a}}$ & $22.21 \pm 1.27^{b}$ & $31.33 \pm 0.31^{\mathrm{c}}$ & $28.54 \pm 0.33^{\mathrm{bc}}$ & $24.84 \pm 1.24^{\mathrm{ab}}$ & $22.29 \pm 0.42^{\mathrm{a}}$ \\
\hline PV & $11.33 \pm 0.07^{\mathrm{a}}$ & $17.16 \pm 0.01^{\mathrm{e}}$ & $15.58 \pm 0.06^{\mathrm{d}}$ & $14.82 \pm 0.03^{\mathrm{c}}$ & $12.40 \pm 0.04^{\mathrm{b}}$ & $13.67 \pm 0.01^{\mathrm{a}}$ & $17.60 \pm 0.04^{\mathrm{b}}$ & $16.45 \pm 0.11^{b}$ & $13.80 \pm 0.14^{\mathrm{a}}$ & $13.02 \pm 0.08^{\mathrm{a}}$ \\
\hline GV & $642.2 \pm 0.1^{\mathrm{a}}$ & $1471.6 \pm 0.3^{\mathrm{e}}$ & $1212.7 \pm 0.1^{\mathrm{d}}$ & $1098.6 \pm 0.2^{c}$ & $768.8 \pm 0.1^{\mathrm{b}}$ & $933.9 \pm 0.2^{\mathrm{b}}$ & $1548.8 \pm 0.3^{\mathrm{d}}$ & $1352.1 \pm 0.4^{\mathrm{c}}$ & $952.2 \pm 0.2^{\mathrm{b}}$ & $847.90 \pm 0.1^{\mathrm{a}}$ \\
\hline SVI & $75.75 \pm 0.1^{\mathrm{a}}$ & $227.06 \pm 0.2^{\mathrm{d}}$ & $218.88 \pm 0.06^{\mathrm{d}}$ & $161.14 \pm 0.11^{\mathrm{c}}$ & $109.81 \pm 0.3^{b}$ & $22.13 \pm 0.23^{\mathrm{a}}$ & $209.44 \pm 0.07^{\mathrm{d}}$ & $210.84 \pm 0.13^{\mathrm{e}}$ & $150.22 \pm 0.02^{\mathrm{c}}$ & $110.05 \pm 0.14^{\mathrm{b}}$ \\
\hline DI & - & $0 \pm 0.00^{\mathrm{a}}$ & $0 \pm 0.00^{\mathrm{a}}$ & $0.5 \pm 0.002^{c}$ & $1 \pm 0.001^{\mathrm{b}}$ & - & $0 \pm 0.00^{\mathrm{a}}$ & $0.2 \pm 0.001^{\mathrm{ab}}$ & $0.5 \pm 0.001^{\mathrm{c}}$ & $1.5 \pm 0.001^{b}$ \\
\hline
\end{tabular}

474 *Within columns, means not followed by the same letter are different at the 0.05 level analysis of variance with Duncan's correction.

475 
478 Fig. 1. a) Root length and shoot height b) Leaf area and c) Total dry biomass of chilli 479 (Capsicum annum) cultivars (GVC-101 and GVC-121) under different treatment (v/v \%) 480 of textile effluent fertilization.

481 Fig. 2. a) chlorophyll ' $a$ ', b) chlorophyll ' $b$ ', c) total chlorophyll and d) carotenoid 482 content in leaves of chilli (Capsicum annum) cultivars (GVC-101 and GVC-121) 30, 60, 48390 and 120 DAS under different treatment (v/v \%) of textile effluent fertilization.

484 Fig. 3. a) Carbohydrate content, b) protein content and c) proline accumulation in leaves 485 of chilli (Capsicum annum) cultivars (GVC-101 and GVC-121) 30, 60, 90 and 120 DAS 486 under different treatment (v/v \%) of textile effluent fertilization. 
Figures
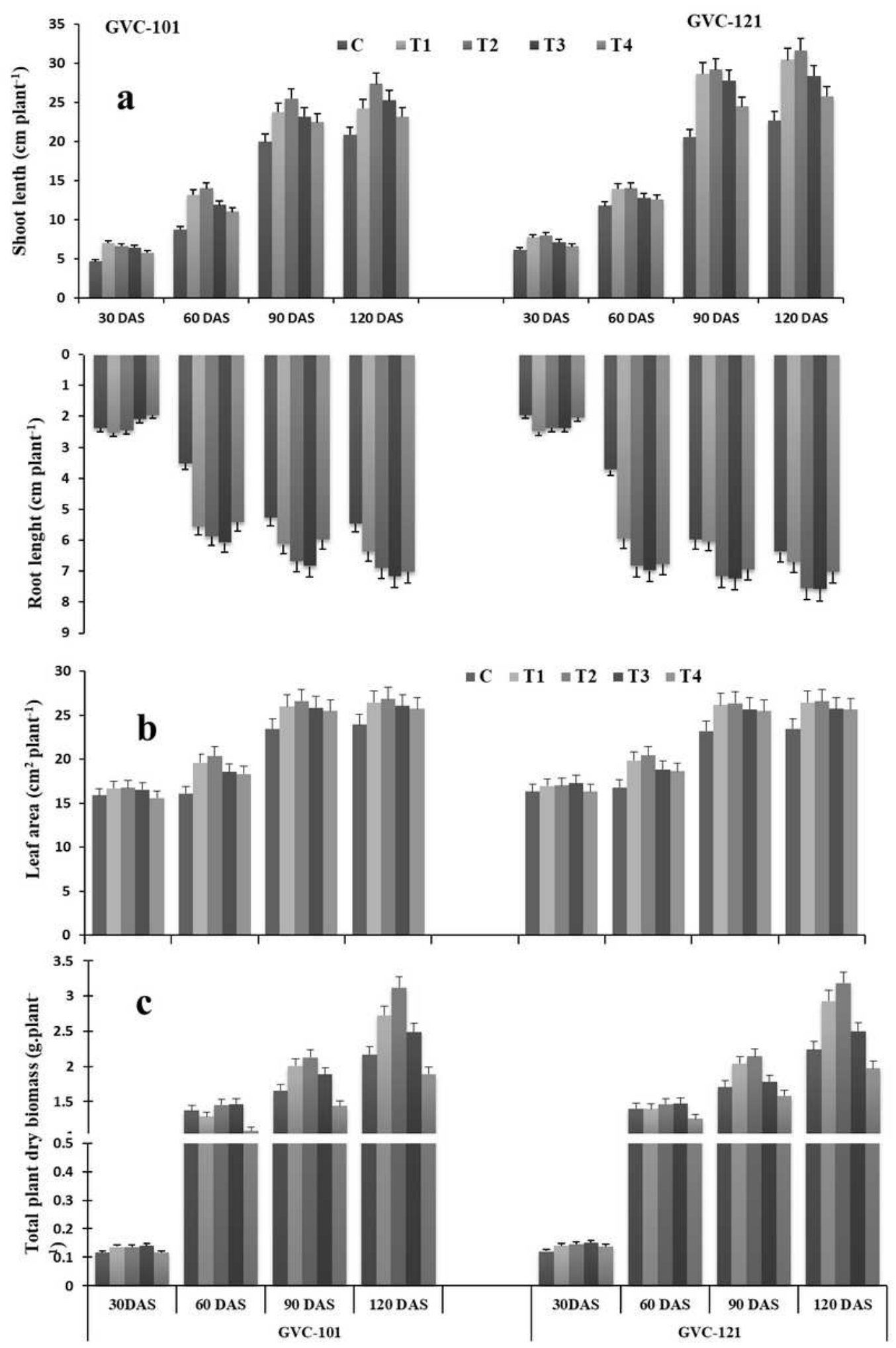

Figure 1

a) Root length and shoot height b) Leaf area and c) Total dry biomass of chilli (Capsicum annum) cultivars (GVC-101 and GVC-121) under different treatment ( $\mathrm{v} / \mathrm{v} \%)$ of textile effluent fertilization. 

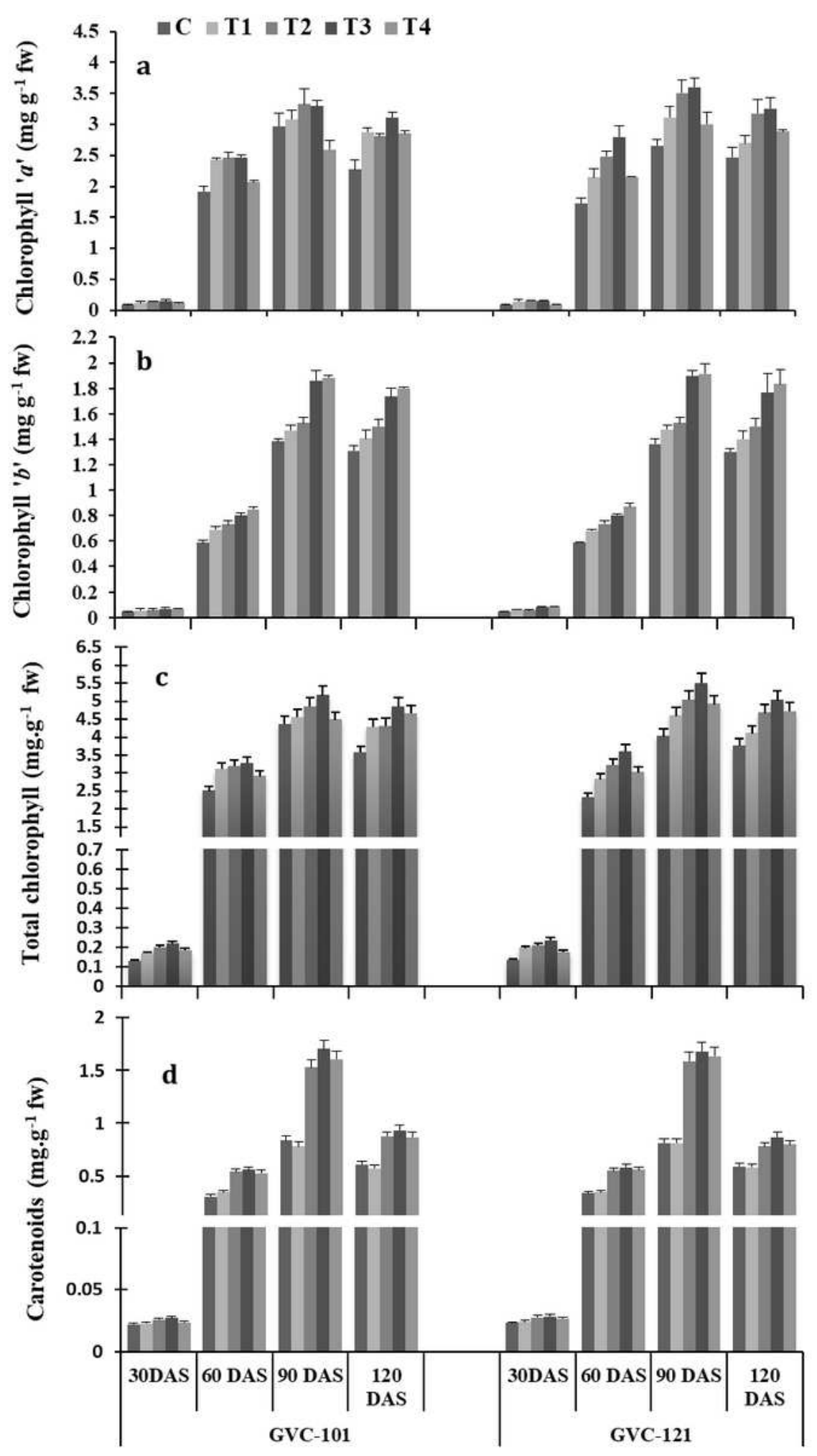

Figure 2

a) chlorophyll 'a', b) chlorophyll 'b', c) total chlorophyll and d) carotenoid content in leaves of chilli (Capsicum annum) cultivars (GVC-101 and GVC-121) 30, 60, 90 and 120 DAS under different treatment $(\mathrm{v} / \mathrm{v} \%)$ of textile effluent fertilization. 

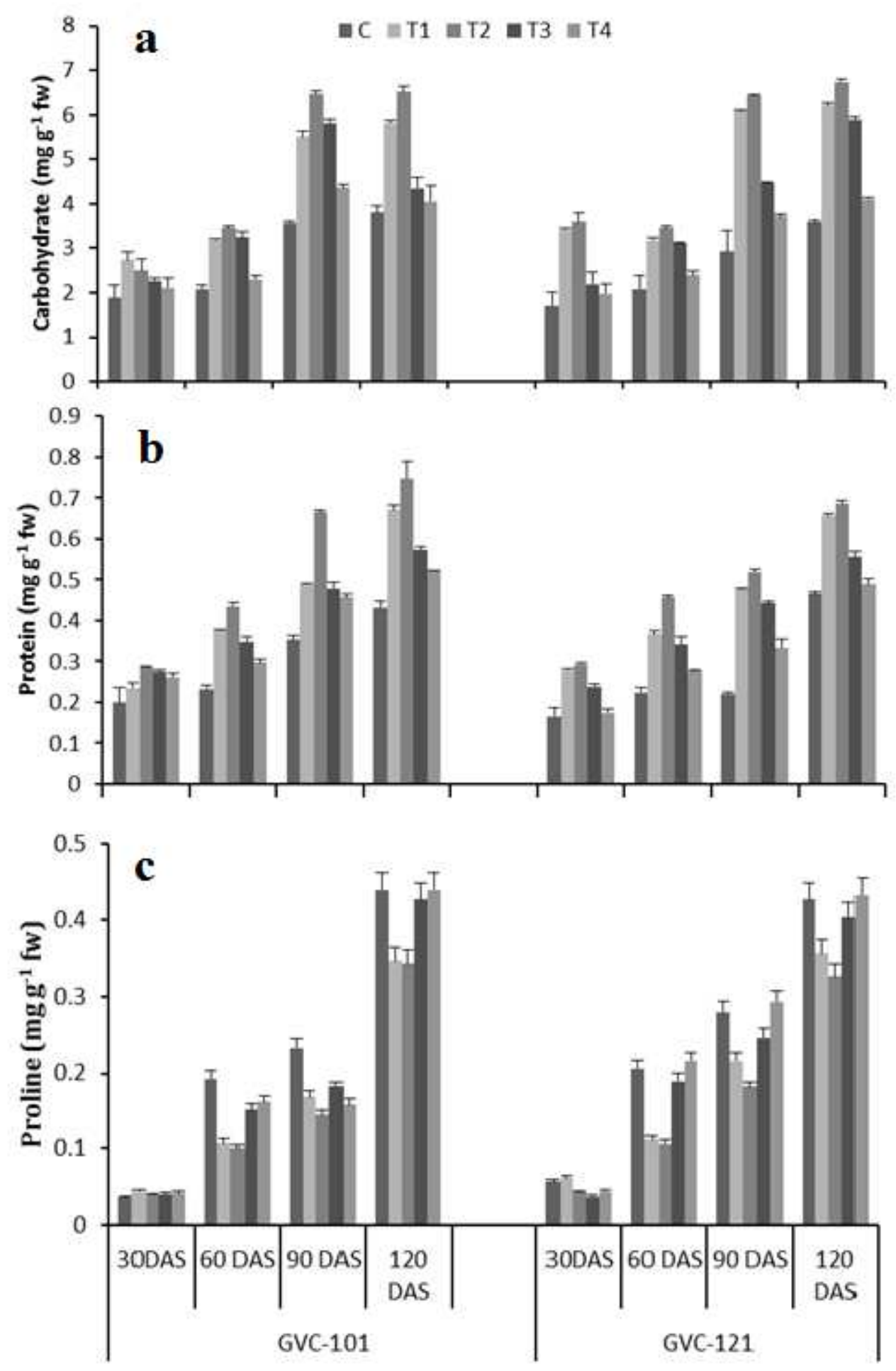

Figure 3

a) Carbohydrate content, b) protein content and c) proline accumulation in leaves of chilli (Capsicum annum) cultivars (GVC-101 and GVC-121) 30, 60, 90 and 120 DAS under different treatment (v/v \%) of textile effluent fertilization.

\section{Supplementary Files}


This is a list of supplementary files associated with this preprint. Click to download.

- SUPPLEMENTRYFILE.docx 